\title{
Analisis Koneksi Matematis Siswa dalam Menyelesaikan Soal Setara TIMSS Ditinjau dari Locus of Control
}

\author{
Nurul Auliyah Sutrisno, a), Didik Sugeng Pambudi ${ }^{1}$, Randi Pratama \\ Murtikusuma $^{1}$ \\ ${ }^{1}$ Universitas Jember \\ Jl. Kalimantan No. 37 Krajan Timur, Sumbersari, Jember, Jawa Timur, Indonesia, 68121 \\ a)nurulaulia1710@gmail.com
}

\begin{abstract}
This study aims to describe the students' mathematical connections in terms of the locus of control. The mathematical connection indicators in this study are writing down the mathematical concepts that underlie the answers, recognize the relationship of various mathematical ideas and mathematical topics that can be related to problems of everyday life, and understand how to solve mathematical ideas that are interrelated and underlie each other to obtain an integrated whole. Data collection methods in this study were questionnaires, tests, and interviews. The subjects of this study were six seventh-grade students at MTs Negeri 7 Jember. The data analyzed by qualitative descriptive analysis. Based on the tests and interviews analysis, we known that students with internal locus of control could write mathematical concepts as a two variable linear equation system (TVLES). Students can connect TVLES material with problems, for example, represented the object in variables $\mathrm{x}$ and $\mathrm{y}$. Students can also solved the problems related to TVLES material by using common examples, elimination and substitution methods. While the students' with external locus of control also can write the mathematical concepts as a TVLES. But the students did not write in detail the relationship between TVLES material and the problem. Students can not solve problems by using TVLES solutions such as elimination and substitution, but students only use estimates in finding solutions.
\end{abstract}

Keywords: mathematical connection; locus of control; TIMSS

\begin{abstract}
Abstrak. Penelitian ini bertujuan untuk mendeskripsikan koneksi matematis siswa ditinjau dari tipe perilaku locus of control. Indikator koneksi matematis dalam penelitian ini adalah menuliskan konsep matematika yang mendasari jawaban, mengenali hubungan dari berbagai representasi ide-ide matematika dan topik matematika yang berkaitan dengan kehidupan sehari-hari, serta memahami cara memecahkan ide-ide matematika yang saling berkaitan dan mendasari satu sama lain untuk memperoleh satu kesatuan yang utuh. Metode pengumpulan data pada penelitian yang digunakan adalah angket, tes, dan wawancara. Subjek penelitian yang terlibat adalah enam siswa kelas VIII A MTs Negeri 7 Jember. Analisis data dalam penelitian ini adalah analisis deskriptif kualitatif. Berdasarkan analisis hasil tes dan wawancara diperoleh keterangan bahwa siswa dengan internal locus of control mampu menuliskan konsep matematika sesuai materi sitem persamaan linier dua variabel (SPLDV). Siswa menghubungkan materi SPLDV dengan soal yaitu dengan memisalkan objek pada soal dengan variabel x dan y. Siswa menyelesaikan soal yang berkaitan dengan materi SPLDV dengan menggunakan pemisalan, eliminasi variabel, dan subtitusi. Sedangkan siswa dengan external locus of control juga mampu menuliskan konsep matematika sesuai materi SPLDV, namun siswa tidak menuliskan secara rinci hubungan materi SPLDV dengan soal. Siswa tidak mampu menyelesaikan soal dengan menggunakan penyelesaian SPLDV seperti eliminasi dan subtitusi, tetapi siswa hanya menggunakan perkiraan saja dalam mencari penyelesaian.
\end{abstract}

Kata kunci: koneksi matematis; locus of control; TIMSS 


\section{PENDAHULUAN}

Matematika merupakan ilmu pendidikan dasar dalam bidang-bidang pengetahuan. Matematika merupakan salah satu bidang yang terdapat pada segala tingkatan pendidikan, mulai tingkat sekolah dasar hingga perguruan tinggi (Susanto, 2013). Ilmu matematika yang bersifat universal harus dipelajari siswa untuk meningkatkan kemampuan siswa dalam menyelesaikan soal matematika (Habibi, Darhim \& Turmudi, 2018). Salah satu soal matematika yang dapat digunakan guru sebagai penilaian adalah soal TIMSS. TIMSS merupakan penilaian internasional di bidang Matematika dan IPA yang sangat baik digunakan untuk mengukur kemampuan siswa di seluruh dunia dengan peserta terdiri dari kelas 4 Sekolah Dasar (SD) dan 8 Sekolah Menengah Pertama (SMP) (TIMSS, 2017). Kemampuan kognitif yang dikembangkan oleh TIMSS adalah pengetahuan (knowing), penerapan (applying), dan penalaran (reasoning) (TIMSS, 2017). Sementara NCTM telah membagi lima prinsip dalam menyelesaikan soal matematika diantaranya adalah pemecahan masalah (problem solving), penalaran dan bukti (reasoning and proof), komunikasi (communication), koneksi (connections), dan representasi (representation) (NCTM, 2000).

Koneksi matematis merupakan salah satu kompetensi yang harus ditingkatkan pada siswa sekolah menengah (BNSP, 2013; NCTM, 2000). Oleh sebab itu, koneksi matematis sangat berperan penting dalam meningkatkan kemampuan siswa dalam menyelesaikan soal TIMSS. Koneksi matematis merupakan kemampuan siswa dalam menghubungkan antar ide-ide matematika, antara ilmu matematika dengan mata pelajaran lain maupun antara matematika dengan kehidupan sehari-hari (NCTM, 2000). Terdapat tiga indikator koneksi matematis, yaitu (1) menuliskan konsep matematika yang mendasari jawaban, pada aspek ini, diharapkan siswa mampu menyebutkan topik-topik matematika yang berkaitan pada soal; (2) mengenali hubungan dari berbagai representasi ide-ide matematika dan topik matematika yang berkaitan dengan masalah kehidupan sehari-hari. Pada aspek ini, diharapkan siswa dapat menjelaskan keterkaitan antar konsep yang digunakan dalam menyelesaikan soal; (3) memahami cara memecahkan ide-ide matematika yang saling berkaitan dan mendasari satu sama lain untuk memperoleh suatu kesatuan yang utuh. Pada aspek ini, diharapkan siswa mampu menuliskan apa yang diketahui, apa yang ditanyakan dan menyelesaikan soal. Berdasarkan penjelasan di atas, analisis koneksi matematis siswa dapat dideskripsikan berdasarkan indikator-indikator dari koneksi matematis pada Tabel 1.

Tabel 1. Indikator Koneksi Matematis

\begin{tabular}{cclc}
\hline No. & \multicolumn{1}{c}{ Indikator Penelitian } & Kriteria \\
\hline 1. & Menuliskan konsep matematika yang mendasari jawaban. & $\begin{array}{l}\text { Menyebutkan topik matematika yang terkait } \\
\text { pada soal. }\end{array}$ \\
\hline 2. & $\begin{array}{l}\text { Mengenali hubungan dari berbagai representasi ide-ide } \\
\text { matematika dan topik matematika yang berkaitan dengan } \\
\text { masalah kehidupan sehari-hari. }\end{array}$ & $\begin{array}{l}\text { Menuliskan hubungan antar konsep } \\
\text { matematika yang berkaitan pada soal. }\end{array}$ \\
\hline
\end{tabular}




\begin{tabular}{llll}
\hline No. & \multicolumn{1}{c}{ Indikator Penelitian } & \multicolumn{1}{c}{ Kriteria } \\
\hline & $\begin{array}{l}\text { Mengenali dan memahami cara memecahkan ide-ide } \\
\text { dalam matematika yang saling berkaitan dan mendasari }\end{array}$ & Menuliskan diketahui atau ditanya. \\
\cline { 2 - 4 } 3. $\begin{array}{l}\text { satu sama lain untuk memperoleh suatu kesatuan yang } \\
\text { utuh. }\end{array}$ & $\begin{array}{l}\text { Menuliskan model matematika } \\
\text { menjawab soal. }\end{array}$ & dalam \\
\hline
\end{tabular}

Pembahasan tentang koneksi matematis yang dibutuhkan dalam menyelesaikan soal TIMSS, tipe perilaku siswa juga mempengaruhi koneksi matematis. Siswa dengan tipe perilaku yang berbeda, memiliki koneksi matematis yang berbeda pula (NCTM, 2000). Tipe perilaku pada penelitian ini adalah locus of control. Locus of control dikemukakan pertama kali oleh Rotter tahun 1966. Selanjutnya, Ada beberapa ahli yang mengemukakan definisi dari locus of control. Pada penelitian Rotter, ia menemukan bahwa beberapa orang yakin akan kekuatan mereka bergantung pada tindakan mereka sendiri dan sebagian orang percaya bahwa kekuatan mereka dikendalikan oleh orang lain atau kekuatan luar (Schultz \& Schultz, 2009).

Jenis perilaku yang telah disebutkan Rotter dicirikan sebagai kepribadian internal locus of control, jenis kepribadian tersebut yakin bahwa penguatan yang mereka terima berasal dari diri mereka sendiri, sedangkan jenis kepribadian external locus of control yakin bahwa nasib, keberuntungan mengendalikan apa yang dia terima (Rotter, 1966). Seseorang yang memiliki tipe perilaku internal locus of control memiliki ciri-ciri diantaranya adalah kepercayaan diri terhadap kemampuannya dalam menyesuaikan soal-soal dan tugas, suka bekerja keras dan berusaha dalam menyelesaikan soal-soal dan mencapai prestasi, dan memiliki kepuasaan diri dalam menyelesaikan tugas tanpa bergantung pada orang lain. External locus of control adalah individu external locus of control tinggi akan mudah putus asa dan pasrah jika mengalami permasalahan yang sulit. Permasalahan tersebut dianggapnya sebagai sebuah ancaman bagi dirinya (Lee et al., 1990).

Hasil penelitian yang relevan menjelaskan bahwa terdapat perbedaan dalam menyelesaikan masalah yang memiliki tipe perilaku yang berbeda. Selain itu, dalam menyelesaikan masalah, siswa bertipe internal lcous of control memiliki sifat percaya diri, memiliki pemahaman yang baik (Abzani \& Leonard, 2017). Beberapa peneliti menyimpulkan bahwa koneksi matematis siswa sekolah masih tergolong rendah dan siswa memiliki tingkat kepercayaan diri yang juga tergolong rendah (Kenedi et al., 2019; Özgen, 2013; Baki et al., 2009). Berdasarkan uraian di atas, penelitian ini bertujuan untuk mendeskripsikan koneksi matematis siswa berdasarkan tipe perilaku locus of control.

\section{METODE}

Daerah pengambilan data adalah di MTs Negeri 7 Jember dengan metode purposive sampling. Jenis penelitian adalah deskriptif dengan pendekatan kualitatif. Pengambilan data menggunakan metode angket, tes, dan wawancara. Soal tes berupa 3 buah soal uraian yang 
dikembangkan dari indikator-indikator koneksi matematis yang terdapat pada Tabel 1. Subjek penelitian diambil dari hasil analisis angket tipe perilaku locus of control yang diberikan kepada sisiwa-siswa kelas VIII A, kemudian diambil 6 siswa yang terdiri atas 3 siswa tipe perilaku internal locus of control (koneksi matematis tinggi, sedang, dan rendah) dan 3 siswa tipe perilaku external locus of control (koneksi matematis tinggi, sedang, dan rendah). Metode analisis data yang digunakan adalah analisis deskriptif kualitatif dengan langkah-langkah: pengumpulan data (angket yang digunakan untuk mengetahui jenis locus of control yang dimiliki oleh siswa, tes koneksi matematis dan wawancara), reduksi data jika diperlukan, penyajian data berupa deskripsi mengenai analisis hasil tes dan hasil wawancara, kemudian penarikan kesimpulan mengenai deskripsi koneksi matematis siswa.

\section{HASIL DAN PEMBAHASAN}

Dari hasil analisis data menunjukkan pada siswa dengan tipe perilaku internal locus of control yaitu $\mathrm{SI}_{1}, \mathrm{SI}_{2}$, dan $\mathrm{SI}_{3}$ memiliki perbedaan dengan siswa dengan tipe perilaku external locus of control yaitu $\mathrm{SE}_{4}, \mathrm{SE}_{5}$, dan $\mathrm{SE}_{6}$. Perbedaan yang terlihat dalam hal ini adalah pencapaian indikator dari hasil tes koneksi matematis. Perbedaan pencapaian indikator pada masing-masing subjek tersebut dapat dilihat berdasarkan Tabel 2.

Tabel 2. Hubungan Antara Setiap Subjek dengan Indikator Koneksi Matematis

\begin{tabular}{|c|c|c|c|c|c|c|}
\hline & $\mathbf{S I}_{1}$ & $\mathbf{S I}_{2}$ & $\mathrm{SI}_{3}$ & $\mathbf{S E}_{4}$ & $\mathbf{S E}_{5}$ & $\mathbf{S E}_{6}$ \\
\hline A1 & $\sqrt{ }$ & $\sqrt{ }$ & $\sqrt{ }$ & $\sqrt{ }$ & $\sqrt{ }$ & $\sqrt{ }$ \\
\hline $\mathrm{A} 2$ & $\sqrt{ }$ & $\sqrt{ }$ & $\sqrt{ }$ & $x$ & $\times$ & $x$ \\
\hline A3 & $\sqrt{ }$ & $x$ & $\times$ & $x$ & $x$ & $x$ \\
\hline \multicolumn{7}{|c|}{ Keterangan: } \\
\hline \multicolumn{7}{|c|}{ A : indikator koneksi matematis } \\
\hline \multicolumn{7}{|c|}{$x$ : tidak memenuhi indikator koneksi matematis } \\
\hline \multicolumn{7}{|c|}{$\sqrt{ }:$ memenuhi indikator koneksi matematis } \\
\hline \multicolumn{7}{|c|}{ SI : siswa internal locus of control } \\
\hline & wa & $f c c$ & & & & \\
\hline
\end{tabular}

\section{Analisis Koneksi Matematis Siswa Internal Locus of Control}

\section{Indikator Menuliskan Konsep Matematika yang Mendasari Jawaban}

Siswa dengan tipe perilaku internal locus of control yaitu $\mathrm{SI}_{1}, \mathrm{SI}_{2}$, dan $\mathrm{SI}_{3}$, mampu memenuhi indikator menuliskan konsep matematika yang mendasari jawaban. Hal ini sejalan dengan hasil penelitian yang menyimpulkan koneksi matematis yang tinggi atau sedang mampu menuliskan konsep yang mendasari jawaban dengan baik (Ni'mah et al., 2017). Berdasarkan hasil 
tes, siswa internal locus of control baik yang memiliki koneksi matematis tinggi, sedang, ataupun rendah mampu menuliskan materi yang berkaitan dengan soal yang terlihat pada Gambar 1 .

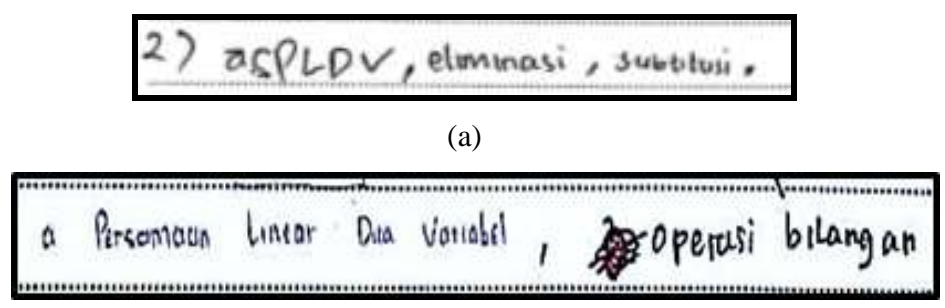

(c)

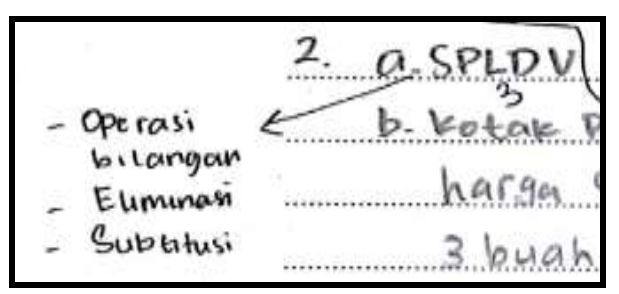

(b)

Gambar 1. Jawaban siswa internal locus of control terhadap soal koneksi matematis (a) subjek $\mathrm{SI}_{1}$; (b) subjek $\mathrm{SI}_{2}$; dan (c) subjek $\mathrm{SI}_{3}$

Berdasarkan uraian di atas, siswa dengan tipe perilaku internal locus of control dapat memenuhi indikator menuliskan konsep matematika yang mendasari jawaban. Hal ini sesuai dengan penelitian yang menjelaskan bahwa siswa dengan internal locus of control mampu memahami pemecahan masalah dengan baik (Bishara \& Kaplan, 2018).Siswa mampu menuliskan konsep matematika yang terdapat pada soal yaitu materi SPLDV.

\section{Indikator Mengenali Hubungan Berbagai Representasi Ide dan Topik Matematika}

Pada indikator ini, siswa mampu mengenali hubungan dari berbagai representasi ide-ide matematika dan topik matematika yang berkaitan dengan masalah kehidupan sehari-hari.

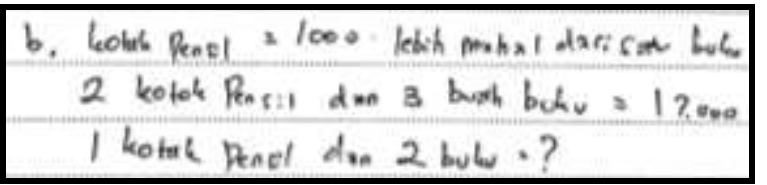

(a)

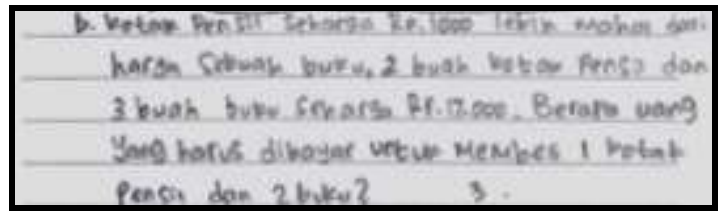

(b)

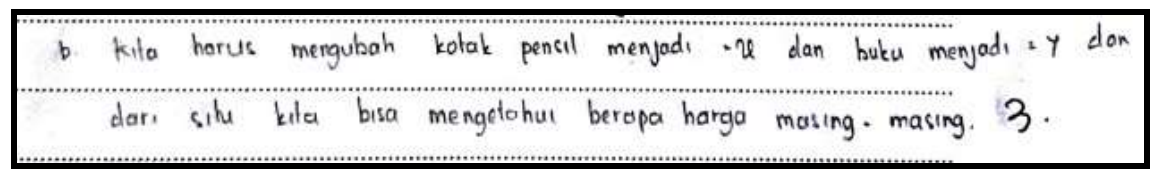

(c)

Gambar 2. Jawaban Siswa Internal Locus of Control terhadap Soal Koneksi Matematis (a) Subjek SI ; $_{\text {; }}$ (b) Subjek $\mathrm{SI}_{2}$; dan (c) Subjek $\mathrm{SI}_{3}$

Berdasarkan Gambar 2, subjek $\mathrm{SI}_{1}$ (Gambar 2(a)) memenuhi indikator menulisakan hubungan konsep matematika yang berkaitan sistem persamaan linier dua variabel. Subjek SI $_{1}$ dan $\mathrm{SI}_{2}$ memenuhi indikator menulisakan hubungan konsep matematika yang berkaitan sistem persamaan linier dua variabel. Hal ini sejalan dengan hasil penelitian yang menyimpulkan koneksi matematis tinggi mampu menuliskan hubungan antara konsep matematika dan objek dengan baik (Ni'mah et al., 2017). Berdasarkan wawancara, subjek $\mathrm{SI}_{1}$ dan $\mathrm{SI}_{2}$ menjelaskan hubungan materi atau konsep matematika dan soal dengan percaya diri. Hal ini sesuai dengan hasil penelitian yang 
menyimpulkan bahwa siswa dengan percaya diri yang tinggi akan mempunyai koneksi matematis yang baik, dikarenakan percaya diri atau self-confidence dapat memperkuat motivasi siswa untuk mencapai keberhasilan dalam menyelesaikan soal (Malinda \& Minarti, 2018; Nurafni \& Pujiastuti, 2019). Subjek $\mathrm{SI}_{2}$ saat wawancara menjelaskan bahwa hubungan konsep dengan soal adalah memisalkan masing-masing variabel dengan $x$ dan $y$. Subjek $\mathrm{SI}_{2}$ mampu menjelaskan hubungan SPLDV dengan soal dengan benar. Subjek $\mathrm{SI}_{3}$ menuliskan hubungan konsep dengan soal yaitu untuk mengetahui harga kotak pensil dan buku harus dilakukan pemisalan kota pensil dimisalkan $x$ dan buku dimisalkan $y$. Subjek $\mathrm{SI}_{3}$ memenuhi indikator menuliskan hubungan konsep matematika yang mendasari jawaban. Saat ditanya kembali untuk memastikan apakah $x$ dan $y$ merupakan persamaan subjek $\mathrm{SI}_{3}$ tidak yakin terhadap jawabannya. Hal ini sesuai dengan hasil penelitian yang menyatakan bahwa siswa yang mempunyai koneksi matematis rendah, juga memiliki kepercayaan diri yang masih kurang (Farida et al., 2018). Subjek $\mathrm{SI}_{3}$ masih belum memahami sepenuhnya hubungan materi SPLDV dengan soal.

Berdasarkan uraian di atas, siswa dengan tipe perilaku internal locus of control memenuhi indikator mengenali hubungan dari berbagai representasi ide-ide matematika dan topik matematika yang berkaitan dengan masalah kehidupan sehari-hari. Siswa mampu menghubungkan materi SPLDV dengan soal yaitu memisalkan objek pada soal dengan variabel $x$ dan $y$.

\section{Indikator Mengenali dan Memahami Cara Memecahkan Ide dalam Matematika}

Pada indikator ini, siswa mampu memenuhi indikator mengenali dan memahami cara memecahkan ide-ide dalam matematika yang saling berkaitan dan mendasari satu sama lain untuk memperoleh suatu kesatuan yang utuh.

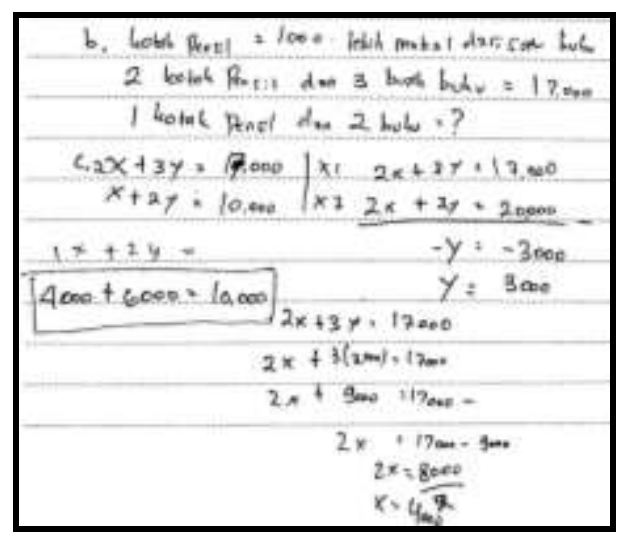

(a)

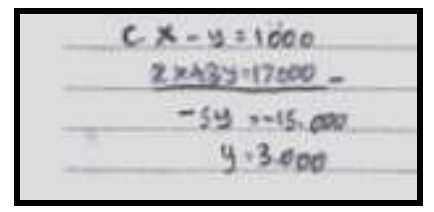

(b)
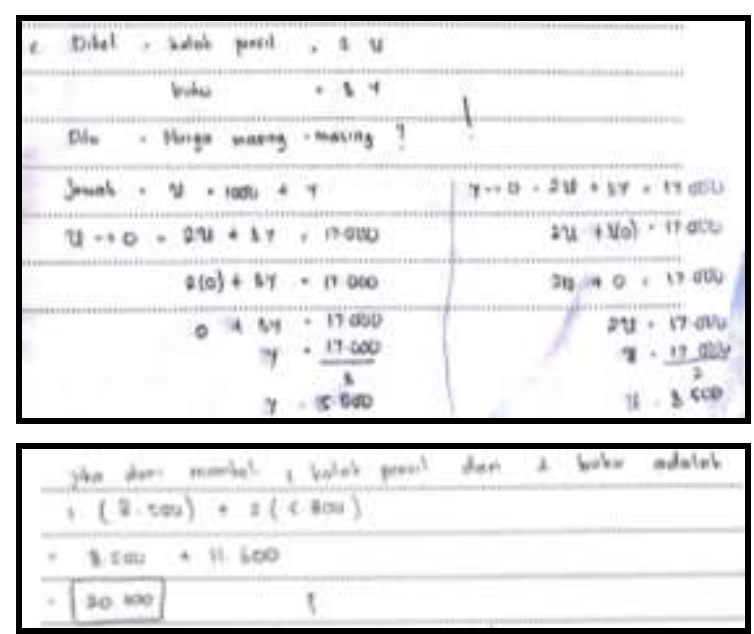

(c)

Gambar 3. Jawaban Siswa Internal Locus of Control terhadap Soal Koneksi Matematis (a) Subjek $\mathrm{SI}_{1}$; (b) Subjek SI ${ }_{2}$; dan (c) Subjek $\mathrm{SI}_{3}$ 
Berdasarkan Gambar 3, subjek $\mathrm{SI}_{1}$ mampu menyelesaikan soal dengan menggunakan konsep eliminasi dan subtitusi pada sistem persamaan linier dua variabel. Subjek $\mathrm{SI}_{1}$ mampu menjelaskan dengan rinci sesuai dengan rencana penyelesaian yang disebutkan pada indikator kedua. Subjek $\mathrm{SI}_{2}$ mampu menyelesaikan soal, namun masih belum lengkap sehingga belum mendapat jawaban dari penyelesaian tersebut. Subjek $\mathrm{SI}_{2}$ hanya mampu menyelesaikan dengan eliminasi dan diperoleh nilai $x=3000$. Subjek $\mathrm{SI}_{2}$ tidak mampu menyelesaikan soal tersebut hingga menemukan apa yang ditanyakan dari soal tersebut. Subjek $\mathrm{SI}_{3}$ masih belum memahami sepenuhnya maksud dari soal tersebut. Subjek $\mathrm{SI}_{3}$ juga masih belum mampu menyelesaikan dengan benar karena untuk mencari nilai $x$ dan $y$ subjek $\mathrm{SI}_{3}$ dengan memisalkan $x=0$ dan $y=0$. Hal ini terlihat bahwa subjek $\mathrm{SI}_{3}$ masih belum memahami konsep sistem persamaan linier dua variabel. Dari ketiga subjek, subjek $\mathrm{SI}_{1}$ saja yang memenuhi indikator mengenali dan memahami cara memecahkan ide-ide dalam matematika yang saling berkaitan dan mendasari satu sama lain untuk memperoleh suatu kesatuan yang utuh. Hal ini sesuai dengan hasil penelitian yang menyimpulkan bahwa siswa dengan koneksi matematis tinggi dapat memenuhi indikator memahami masalah kehidupan seharihari dalambentuk model matematika dengan baik (Ni'mah et al., 2017).

Berdasarkan uraian di atas, siswa dengan tipe perilaku internal locus of control memenuhi indikator mengenali dan memahami cara memecahkan ide-ide dalam matematika yang saling berkaitan dan mendasari satu sama lain untuk memperoleh suatu kesatuan yang utuh. Hal ini sesuai dengan hasil penelitian bahwa menyimpulkan bahwa semakin tinggi kompetensi siswa yang berkaitan dengan kemampuan pemecahan masalah, maka semakin tinggi pula kecenderungan siswa tersebut memiliki tipe perilaku internal locus of control (Abzani \& Leonard, 2017; Konan, 2013). Siswa mampu menyelesaikan soal yang berkaitan dengan materi SPLDV dengan menggunakan pemisalan, eliminasi variabel, dan subtitusi.

\section{Analisis Koneksi Matematis Siswa External Locus of Control}

\section{Indikator Menuliskan Konsep Matematika yang Mendasari Jawaban}

Siswa dengan tipe perilaku external locus of control yaitu $\mathrm{SE}_{4}, \mathrm{SE}_{5}$, dan $\mathrm{SE}_{6}$, mampu memenuhi indikator menuliskan konsep matematika yang mendasari jawaban. Berdasarkan hasil tes, siswa external locus of control baik yang memiliki koneksi matematis tinggi, sedang, ataupun rendah mampu menuliskan materi yang berkaitan dengan soal.

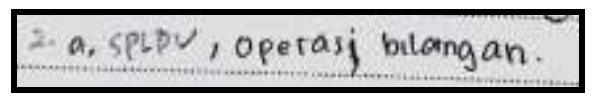

(a)

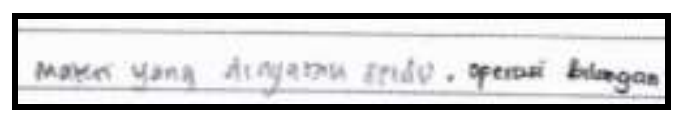

(b)

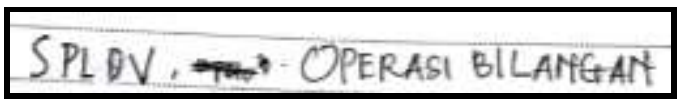

(c)

Gambar 4. Jawaban Siswa External Locus of Control terhadap Soal Koneksi Matematis (a) Subjek $\mathrm{SE}_{4}$; (b) Subjek $\mathrm{SE}_{5}$; dan (c) Subjek $\mathrm{SE}_{6}$ 
Berdasarkan Gambar 4, ketiga subjek menuliskan materi yang berakitan dengan soal adalah sistem persamaan linier dua variabel. Berdasarkan uraian di atas, siswa dengan tipe perilaku external locus of control dapat memenuhi indikator menuliskan konsep matematika yang mendasari jawaban. Hal ini tidak sesuai dengan teori yang menjelaskan bahwa siswa external locus of control tidak mampu memahami pemecahan masalah (Bishara \& Kaplan, 2018). Siswa mampu menuliskan konsep matematika yang terdapat pada soal yaitu materi SPLDV.

\section{Indikator Mengenali Hubungan Dari Berbagai Representasi Ide dan Topik Matematika}

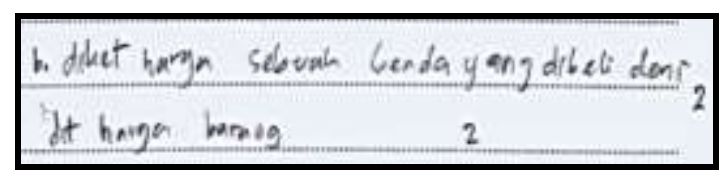

(a)

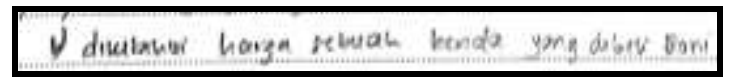

(b)

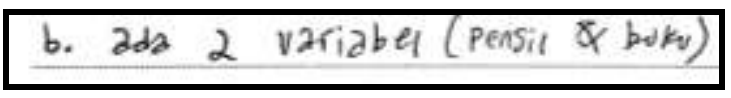

(c)

Gambar 5. Jawaban Siswa External Locus of Control terhadap Soal Koneksi Matematis (a) Subjek SE 4 ; (b) Subjek SE ; dan (c) Subjek $\mathrm{SE}_{6}$

Berdasarkan Gambar 5, saat wawancara subjek $\mathrm{SE}_{4}$ kurang mampu menjelaskan secara lengkap tentang hubungan antara konsep dan soal tersebut dan tidak dapat menunjukkan persamaan dengan benar. Subjek $\mathrm{SE}_{5}$ menuliskan hubungan konsep dengan soal yang diberikan yaitu Kaitannya dengan SPLDV ada dua pemisalan yaitu persamaan $x$ dan $y$ serta $x=3000$ dan $y=4000$. Berdasarkan wawancara subjek $\mathrm{SE}_{5}$ menjelaskan bahwa hubungan konsep dengan soal adalah memisalkan masing-masing variabel dengan $x$ dan $y$, subjek $\mathrm{SE}_{5}$ memperoleh nilai $x=4000$ dan $y$ $=3000$ dengan menggunakan perkiraan. Terlihat bahwa subjek $\mathrm{SE}_{5}$ kurang percaya diri dengan jawabannya dikarenakan cara menyelesaikan soal yaitu dengan perkiraan nilai dari $x$ dan $y$. Subjek $\mathrm{SE}_{6}$ menuliskan hubungan konsep dengan soal yaitu ada dua variabel yang terdiri dari pensil dan buku. Subjek $\mathrm{SE}_{6}$ tidak dapat menjelaskan secara lengkap bagaimana hubungan soal nomor 2 dengan SPLDV. Subjek $\mathrm{SE}_{6}$ merasa kebingungan ketika ditanya perihal jawaban yang ditulis. Hal ini terlihat bahwa subjek kurang percaya diri dalam menjelaskan jawaban yang telah ditulis. Hal ini diperkuat dengan pernyataan yang menyatakan bahwa subjek external locus of control mudah terburu, cemas, dan kurang percaya diri terhadap pekerjaan yang diselesaikannya (Keta, 2018). Berdasarkan uraian di atas, siswa dengan tipe perilaku external locus of control tidak memenuhi mengenali hubungan dari berbagai representasi ide-ide matematika dan topik matematika yang berkaitan dengan masalah kehidupan sehari-hari. Siswa tidak menuliskan secara rinci hubungan materi SPLDV dengan soal. Hal ini sesuai dengan teori yang menyatakan bahwa siswa dengan tipe 
EDUMATIKA: Jurnal Riset Pendidikan Matematika

e-ISSN 2620-8911

Volume 3, Nomor 1, Mei 2020

p-ISSN 2620-8903

perilaku external locus of control tidak dapat membuat suatu rencana penyelesaian dalam menyelesaikan masalah dengan baik (Abzani \& Leonard, 2017). Siswa tidak menuliskan secara rinci hubungan materi SPLDV dengan soal.

\section{Indikator Mengenali dan Memahami Cara Memecahkan Ide-Ide dalam Matematika}

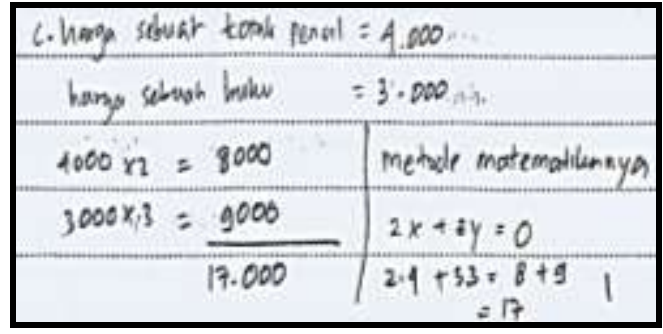

(a)

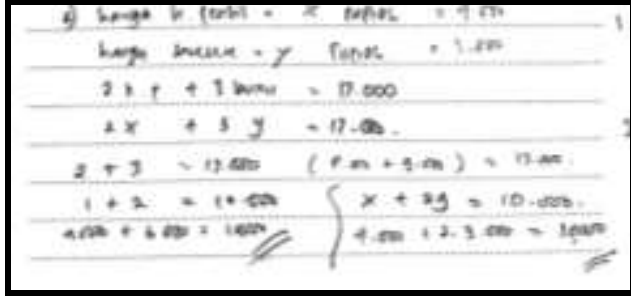

(b)
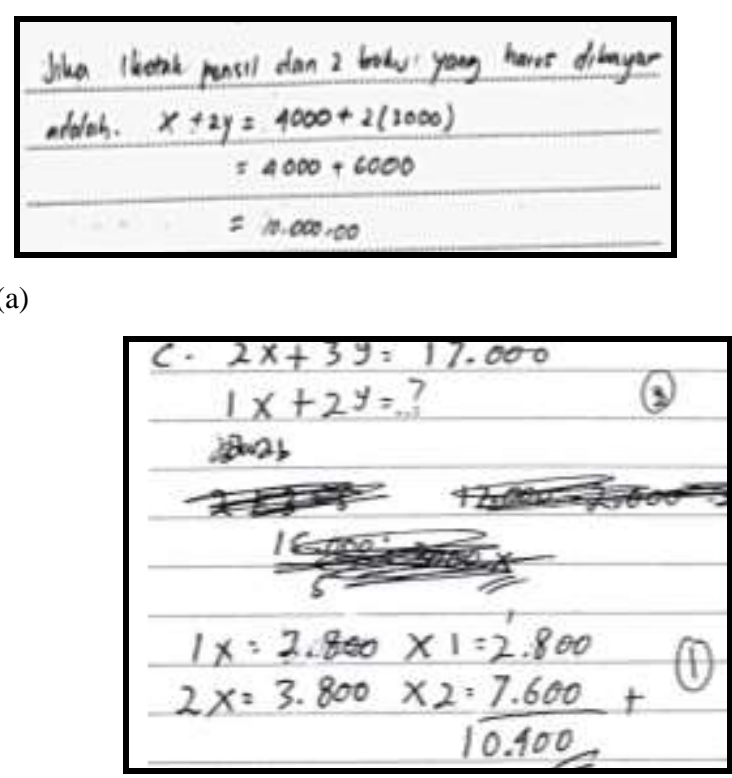

(c)

Gambar 6. Jawaban Siswa External Locus of Control terhadap Soal Koneksi Matematis (a) Subjek $\mathrm{SE}_{4}$; (b) Subjek $\mathrm{SE}_{5}$; dan (c) Subjek $\mathrm{SE}_{6}$

Subjek $\mathrm{SE}_{4}$ belum dapat menyelesaikan dengan tepat dikarenakan subjek $\mathrm{SE}_{4}$ hanya menggunakan perkiraan jawaban dalam menjawab soal. Berdasarkan hal tersebut, diperoleh bahwa subjek $\mathrm{SE}_{4}$ belum memahami sepenuhnya mengenai materi SPLDV. Subjek $\mathrm{SE}_{5}$ belum dapat menyelesaikan dengan tepat dikarenakan subjek $\mathrm{SE}_{5}$ hanya menggunakan perkiraan jawaban dalam menjawab soal. Berdasarkan hal tersebut, diperoleh bahwa subjek $\mathrm{SE}_{5}$ belum memahami sepenuhnya mengenai materi SPLDV. Berdasarkan hal tersebut subjek $\mathrm{SE}_{6}$ masih belum memahami sepenuhnya maksud dari soal tersebut.

Berdasarkan uraian di atas, siswa dengan tipe perilaku external locus of control tidak memenuhi indikator mengenali dan memahami cara memecahkan ide-ide dalam matematika yang saling berkaitan dan mendasari satu sama lain untuk memperoleh suatu kesatuan yang utuh. Hal ini sesuai dengan teori yang menjelaskan bahwa semakin rendah kompetensi siswa mengenai kemampuan pemecahan masalah, semakin tinggi kecenderungan siswa tersebut memiliki tipe perilaku external locus of control (Abzani \& Leonard, 2017; Konan, 2013). Siswa dengan tipe perilaku external locus of control tidak mampu menyelesaian soal dengan menggunakan 
penyelesaian SPLDV seperti eliminasi dan subtitusi, tetapi siswa hanya menggunakan perkiraan saja dalam mencari penyelesaian.

\section{KESIMPULAN}

Berdasarkan rumusan masalah dan analisis hasil pembahasan, dapat disimpulkan bahwa siswa internal locus of control mampu menuliskan konsep matematika yang terdapat pada soal yaitu materi SPLDV. Siswa mampu menghubungkan materi SPLDV dengan soal yaitu memisalkan objek pada soal dengan variabel $x$ dan $y$. Siswa mampu menyelesaikan soal yang berkaitan dengan materi SPLDV dengan menggunakan pemisalan, eliminasi variabel, dan subtitusi. Siswa external locus of control mampu menuliskan konsep matematika yang terdapat pada soal yaitu materi SPLDV. Siswa tidak menuliskan secara rinci hubungan materi SPLDV dengan soal. Siswa tidak mampu menyelesaikan soal dengan menggunakan penyelesaian SPLDV seperti eliminasi dan subtitusi, tetapi siswa hanya menggunakan perkiraan saja dalam mencari penyelesaian.

\section{DAFTAR RUJUKAN}

Abzani, \& Leonard. (2017). Pengaruh Locus of Control terhadap Kemampuan Pemecahan Masalah Matematika. In Prosiding Diskusi Panel Nasional Pendidikan Matematika, 2581-0812, 549-558.

Baki, A., Çatlioğlu, H., Coştu, S., \& Birgin, O. (2009). Conceptions of High School Students About Mathematical Connections to the Real-Life. Procedia - Social and Behavioral Sciences, 1(1), 14021407. https://doi.org/10.1016/j.sbspro.2009.01.247

Bishara, S., \& Kaplan, S. (2018). The Relationship of Locus of Control and Metacognitive Knowledge of Math with Math Achievements. International Journal of Disability, Development and Education, 65(6), 631-648. https://doi.org/10.1080/1034912X.2018.1432033

BNSP. (2013). Kerangka Dasar dan Struktur Kurikulum Sekolah (Issue Standar Penilaian Pendidikan, 1234). https://doi.org/10.1017/CBO9781107415324.004

Farida, E., Alauzi, F. A., \& Zanthy, L. S. (2018). Analisis Koneksi Matematis Siswa dan Kepercayaan Diri Siswa SMP. Journal On Education, 1(4), 688-695.

Habibi, M., Darhim, D., \& Turmudi, T. (2018). Self-Determination in Mathematics Learning Process by Using Generative Multi-Representation Learning (GMRL) Model. In Journal of Physics: Conference Series, 1097(1), 012155

Kenedi, A. K., Helsa, Y., Ariani, Y., Zainil, M., \& Hendri, S. (2019). Mathematical Connection of Elementary School Students to Solve Mathematical Problems. Journal on Mathematics Education, $10(1), 69-80$.

Keta, D. P. (2018). Analisis Interaksi Gender dan Locus of Control Serta Pengaruhnya terhadap Professional Judgement. Jurnal Akuntansi, 6(1), 1-17.

Konan, N. (2013). Relationship between Locus of Control and Problem-Solving Skills of High School Administrators. International Journal Social Science \& Education, 3(3), 786-794.

Lee, C., Ashford, S. J., \& Bobko, P. (1990). Interactive Effects of "Type A" Behavior and Perceived Control on Worker Performance, Job Satisfaction, and Somatic Complaints. Academy of Management Journal, 33(4), 870-881. https://doi.org/10.5465/256296

Malinda, P., \& Minarti, E. D. (2018). Pengaruh Self Confidence Terhadap Kemampuan Koneksi Matematis Siswa SMP. Jurnal Pendidikan Tambusai, 2(6), 1829-1837.

NCTM. (2000). Principles and Standards for School Mathematics (I. Mullis \& M. Michael (eds.)). Key Curriculum Press.

Ni'mah, A. F., Setiawani, S., \& Oktavianingtyas, E. (2017). Analisis Kemampuan Koneksi Matematika Siswa Kelas IX A MTs Negeri 1 Jember Subpokok Bahasan Kubus dan Balok (The Analysis of 
Mathematic Connection Capability Grade IX A MTs Negeri 1 Jember Subchapter Cube and Block). Jurnal Edukasi, 4(1), 30-33.

Nurafni, A., \& Pujiastuti, H. (2019). Analisis Kemampuan Koneksi Matematis Ditinjau dari Self Confidence Siswa: Studi Kasus Di SMKN 4 Pandeglang. ANARGYA: Jurnal Ilmiah Pendidikan Matematika, 2(1), 62-67.

Özgen, K. (2013). Self-Efficacy Beliefs in Mathematical Literacy and Connections Between Mathematics and Real World: The Case of High School Students. Journal of International Education Research (JIER), 9(4), 305. https://doi.org/10.19030/jier.v9i4.8082

Rotter, J. B. (1966). Generalized expectancies for internal versus external control of reinforcement. Psychological monographs: General and applied, 80(1), 1.

Schultz, D. P., \& Schultz, S. E. (2009). Theories of Personality. Wadsworth Cengage Learning.

Susanto, A. (2013). Teori Belajar dan Pembelajaran di Sekolah Dasar. Prenamedia Group.

TIMSS. (2017). TIMSS 2019 Assessment Frameworks. TIMSS \& PIRLS International Study Center. 